\section{DIGITAL COMMONS \\ @ UNIVERSITY OF SOUTH FLORIDA}

\section{ABO: Interactive Journal for Women in the Arts, 1640-1830}

\title{
Interactive Aphra: Skyping Behn into your Classroom
}

Cheryl Wanko

West Chester University, CWanko@wcupa.edu

Follow this and additional works at: https://digitalcommons.usf.edu/abo

Part of the Dramatic Literature, Criticism and Theory Commons, Educational Methods Commons, Feminist, Gender, and Sexuality Studies Commons, and the Literature in English, British Isles Commons

\section{Recommended Citation}

Wanko, Cheryl (2013) "Interactive Aphra: Skyping Behn into your Classroom," ABO: Interactive Journal for Women in the Arts, 1640-1830: Vol.3: Iss.1, Article 6.

http://dx.doi.org/10.5038/2157-7129.3.1.6

Available at: https://digitalcommons.usf.edu/abo/vol3/iss1/6

This New Media is brought to you for free and open access by Digital Commons @ University of South Florida. It has been accepted for inclusion in ABO: Interactive Journal for Women in the Arts, 1640-1830 by an authorized administrator of Digital Commons @ University of South Florida. For more information, please contact digitalcommons@usf.edu. 


\title{
Interactive Aphra: Skyping Behn into your Classroom
}

\begin{abstract}
Beginning by asking how teachers manage the presence of the author in their literature classrooms, this article describes the classroom experiment of interviewing Karen Eterovich, an actor who portrays Aphra Behn, using Skype. It describes the planning and scripting processes, explains the particular interests of this group of students, and assesses the final activity. Questions arose about topics for the interview, appropriate ways for Behn to respond, and the need for a script. The pedagogical opportunities for preparing students as interviewers and of expanding their understanding of performance, historical reenactment, and the construct of the author are discussed. Possible extensions of this technique for other types of classes are suggested.
\end{abstract}

\section{Keywords}

Aphra Behn, Skype, Karen Eterovich, distance learning, interactive, media, historical reenactment, interview, impersonation, author

\section{Creative Commons License} (c) (1) $\odot$

This work is licensed under a Creative Commons Attribution-No Derivative Works 3.0 License. 
Which famous author, dead or alive, would you most like to meet? You may have your answer ready, but I've always disliked this surprisingly common question. Who am I to chat about writing with, say, Jane Austen? She would arch an eyebrow, and I would flee in mortification, hoping she couldn't Google any of my past articles. And what would I ask Shakespeare beyond, “Could you settle the Francis Bacon question once and for all, please?”

But when I started reading the works of Aphra Behn seriously in the 1980s, I knew I had found the famous author I would most like to meet-more specifically, the one I'd most like to meet in a pub. How could she not be good company? Passionate, practical, hard-working, and plainspeaking, with exciting friends about whom to gossip and astonishing adventures to relate. One feels one could easily slip from politics to girl talk with her, through all topics in between, as one can with one's best female friends.

So when I was planning a revised version of my junior-/senior-level English research seminar on Behn, I thought about classroom interaction with the subjects of our literary and historical study and how our sense of the author-as-person is created. How do classes of all types manage the presence of the author in the room? One can, of course, ignore the author and look only at the texts, since texts are all we really have, but most of us know the impossibility of avoiding biography and its sister, authorial intention, in a classroom. Instructors often provide a biographical introduction or assign that to students. We ask students to read biographical material, both modern and contemporary, to help them understand the historical construction of the author. We both read biographical information into an author's works and infer biographical information from those works. We need authors to have existed, and we will create them, somehow.

A happy confluence of conditions allowed me to approach the question of the author's presence in an additional way for this class, though, as I hope to suggest later, I don't believe these conditions are the only ones under which my approach could work. First, I had the luxury of devoting a full semester to Behn's work in this special-topics course. Second, I had developed a professional connection with Karen Eterovich, with whom most readers of $A B O$ are familiar because of her one-woman show, Love Arm'd: Aphra Behn and her Pen, and I held a high regard for her work. The last time I taught my Behn seminar, in 2001, I had hosted Karen's show on my campus, and, for a Restoration and eighteenth-century drama course in 2004, I had hired Karen to sweep indignantly into my classroom in full Aphra get-up as we were discussing The Rover, to demand what we meant by "deconstructing" it and examining its "deployment of semiotic power.” So I had prior models for bringing Behn to life via performance. But, as at most colleges and universities, money and scheduling are tighter now, so hosting the show on campus again wouldn't be possible. There had to be some other way to bring Karen's version of Behn into the classroom.

However, there was one more fortuitous condition: the availability, since 2003, of Skype. Not that I had much experience with Skype. None, actually, but how hard could it be? Just knowing that certain technological tools exist allow us to problem-solve in creative ways, and knowing about Skype allowed me to propose something new. I e-mailed Karen, who was-and still isenjoying the success of her Jane Austen show (Cheer from Chawton: A Jane Austen Family Theatrical), and made the pitch: 
I know you're feeling more Austen-y these days, but I've been thinking about the Aphra seminar I am teaching again in the spring, and I'm wondering whether or not Aphra would enjoy doing a Skype interview with my class? ... We could hook up Skype in class and talk to her in person for about an hour, from the privacy of her own home. ... I'm sure I could shake a few bucks loose somewhere on campus. . .

I unashamedly wheedled from the economic angle, stating that this might be a way to move Aphra (and Jane?) into twenty-first-century technology, originating a new type of interactive performance. Karen was willing, so we set up some dates for my class and for testing Skype from our classroom ahead of time over spring break, to work out any kinks. I bought a cheap webcam (now most laptops come with them built in). We had two test runs that assured us all would go smoothly.

My class was well into the works of Behn by the time our interview occurred in the last month of the semester. We had examined some of her poetry, three plays, some short fiction, and Oroonoko (both Behn's original and Southerne's dramatic version - see syllabus in Appendix). In the weeks leading up to the interview, I asked students to brainstorm questions for Behn: what would we like to know about her? Groups of students, of course, develop languages and shared experiences that inform and fuel their class interactions; they also become fixated on certain themes, questions, and interpretative angles. This class was no different. First, they wanted to know if Behn's truth claims - that she was physically there - were true. Not only did they want clarification of biographical incidents (e.g. did she spend time in prison after she returned from her spying venture?), but they also were curious about what her narrators claim in her stories. Did she really plan to take vows, as her narrator asserts in The History of a Nun? Was she the narrator of "The Disappointment" and "To the Fair Clarinda" - and did she really have the sexual experiences these poems describe?

The sex question was, unsurprisingly, this class's second obsession, especially the bisexuality of Behn's lover, John Hoyle. The class possessed an amazing ability to see bisexuality everywhere; perhaps this was a version of the usual student disbelief that people "back then" knew about such things, much less engaged in them. Behn need only use the word "secret" in a poem, and my students became agitated and exclaimed that, of course, what other secret could she possibly be alluding to besides Hoyle's bisexuality? Little I said could dissuade them: that she may have known quite a few people who had a range of sexual experiences - after all, she was friends with Rochester-so she may not have thought as much about Hoyle's bisexuality as she did about his callousness and infidelity. Or that their reading didn't quite make sense given the rest of the poem/play/story/novel. Or that assuming Behn could only be writing about a man (a suspicion commonly held about many female writers) — and not others' desires or her own secrets—did a disservice to her work as a writer and underestimated her writerly imagination. By the time this class was done reading some of her works, they had me in such a state that I too wanted to corner Aphra and ask her, just so we could move on.

While I had considered that, ideally, the class could rattle off questions and Karen could ad lib as Aphra, it was only my inexperience in acting that allowed me to think this would work. Karen 
disabused me, saying she didn't want to be responsible for putting words into Aphra's mouth on all possible topics a class of students could dream up, from "What's your favorite color?" to "What did you mean in line seven of your poem, 'To My Lady Morland at Tunbridge'?” As a condition of Aphra's arising from the dead for this one interview, the class would have to submit questions in advance. So the class engaged in an activity similar to planning any other type of interview, from journalistic projects to ethnographic research. Given what we knew about Behn, what would be reasonable and respectful questions? While Behn seemed open to writing about sex, we couldn't predict how she would react to, “Did you have sex with women?” We couldn't just jump in and quiz her about Hoyle-Behn would be justified in cutting the Skype connection. We needed to plan carefully if we wanted to raise topics that were even more sensitive then than they are today.

The class generated a list of questions that it then interrogated, narrowed, and organized. We asked, "What would Terry Gross do?” Then we explored possible follow-ups and transitions between questions. The final list of nineteen began with "How were you educated?", moved through her spying and writing experiences - especially as a woman in a male-controlled theatre culture-before broaching the inevitable, "In regards to John Hoyle, how did you find out he was bisexual, and how did you feel about that?” The interview would conclude with-in my students' words - “What are your feelings on Virginia Woolf's 'shout out'?” (Aphra was quite confused about what this meant, as you might imagine: they were referring to Woolf's words in A Room of One's Own, "All women together ought to let flowers fall upon the tomb of Aphra Behn ... for it was she who earned them the right to speak their minds” [Ch. 4])

I supplied the list of questions to Karen, and we began thinking about important performance issues. How should she answer these questions? Karen wanted to use as many of Behn's words as possible - those she had already assembled for her show, as well as others available in Behn's works and recorded in biographies. So our final script was indeed a script: the class composed the list of questions; I sent it to Karen; and Karen used her material to devise responses to the questions, though the students did not see them until after the interview. Karen rehearsed extensively, because, as she said, "I really don't want to be too pause-y when I am talking to them, not with a mind like Aphra Behn’s - that mind was like the speed of light.”

The day arrived, and students (plus a couple of guests-it's always good to invite the department when you're spending university money) had their interview questions ready. The class session lasted one and a quarter hours, so we figured on a half hour for the interview, a half hour to discuss Karen's acting career and other performance topics, and fifteen minutes for potential technical difficulties. We cranked up Skype, set the webcam to pan the room, and welcomed Mistress Behn: she responded, "G'day to you! It seems a few of my friends have transported me here. I'm not even sure where 'here' is, but I can see for myself that I am looking into some sort of glass and seeing other people dressed in a most extraordinary way." I first asked Behn to recite some of her poetry - the class wanted "The Disappointment," but we agreed that would be too long, so we settled on "Love Arm'd” and "Love Reveng'd." Hearing a trained voice recite helped the class understand more of the interpretative possibilities in Behn's verse as well as helped establish the tone for the interview. 
I had told the students as little as possible about who would be on the other side of Skype. They seemed surprised and pleased when a woman in period costume with wig-and wine glassmaterialized and spoke to them with a British accent. My usually outspoken class became suddenly shy, which also underscores the usefulness of a pre-arranged script. They soon rallied and asked their questions, following up as necessary.

After the interview, Karen dropped her role and spoke with students about choosing Behn as the subject for a one-woman play, about her past performances, her training, etc. We spoke about twenty-first century acting practices in comparison to those of Behn's day. Some members of the class had traveled to New York to see a production of The Rover, a play the full class had read, so we talked specifically about that play. After Karen and I logged out of Skype, the students and I chatted about the session, and then she and I were able to discuss this feedback when we debriefed. Our main planned revision would be to smooth out the conclusions of her responses that used Behn's words, since sometimes her answers seemed incomplete and needed to be brought back into the context of the interview.

Though it was a lot of fun, several important pedagogical purposes were served by this exercise as well. How many English majors want to be journalists? How many will end up in management positions, for which they will be running meetings or employment interviews? Our students need to be able to conduct interviews professionally. The imaginative experiment of planning the questions, considering how they might be received, and thinking about possible follow-ups was good training. How many will have to work via videoconferencing? They saw first-hand what this might be like in a more formal setting than their usual Skype or FaceTime calls.

The exercise also caused us to think more about performance itself and about performing the past. What topics would be improper for Aphra to discuss? Should Karen answer only from within a seventeenth-century set of mores, or also try to connect with modern assumptions? Is it okay if Karen ad libs as Aphra? If she only uses Aphra's own words, does that take them out of their original contexts and use them in ways that are as artificial as ad libbing? Karen's Aphra was sometimes evasive and often took on a storytelling diction that clearly derived from her reliance on Behn's texts. Whether or not students heard this as stilted or mellifluous, we could debate the effects of language change and of the demands of older language on actors and readers. And when Behn doesn't understand what a "shout out" means, we can look for parallels in seventeenth-century terminology, or question whether the concept would even have existed at that time.

Although one can obtain acting lessons and accent coaching via Skype, it seems as though our class and Karen were the first to attempt our particular combination of distance learning, interactive media, historical reenactment, and professional interview. But the question of how one makes a performance represent a once-living human being is one that all practitioners of "living history" and historical reenactment, from stage performances to the Society for Creative Anachronism to Colonial Williamsburg, must face. Classes could easily adapt the Skype technique to other, related applications. Many actors have made careers out of performing as authors: Google turns up Emily Dickinson, Mark Twain, and Frederick Douglass impersonators galore. Charles Dickens seems to have so many impersonators that we're all probably fewer 
than six degrees away from one-the Free Library of Philadelphia even hosted a "Charles Dickens Idol” contest for impersonators. My relationship with Karen was built over many years, so I was familiar with her understanding of Behn and her performance preferences. Making contact with someone new might offer you or your students the initial exercise of figuring out which impersonator to invite, or, if you teach a class on Victorian literature, you might be able to interview several Dickenses to discuss competing reanimations. Everyone has had the experience of reading a novel and then seeing its film adaptation, so one could take advantage of the reaction "I didn't picture XYZ like that," to consider where the portrayal seemed "off” and why: what baggage do we bring to performance, and which texts should be privileged when constructing a character? Via Skype, one could invite into one's class re-enactor representatives of great debates: from the American Revolution, for example, or the English Civil War. One could partner a literature class with an acting class, to highlight how the two disciplines often read dramatic texts much differently, or with a history class, to combine the two classes' expertise in discussing questions of politics or women's roles. The pedagogical opportunities multiply quickly.

The importance of studying women writers is taken for granted, but new media allows us to encourage women from the past to speak in other ways. For example, the $A B O$ website includes an "Ask Aphra" section that provides a type of talkback similar to my class's experience, though on issues with which Aphra and her friends would have had minimal experience. "Ask Aphra” is reimagining - or re-enacting - the spirit of Aphra, giving her an amiable circle that we hope she also enjoyed in the seventeenth century, and transporting them to an academic advice column setting. What are Behn's historically transferable characteristics and do we have a current occupation that organizes those characteristics in a way that would have allowed her to flourish? Would Aphra today be a columnist, or a Hollywood script doctor, or . . . ? Idle speculation, perhaps, leading to ahistorical dead ends. But this is essentially the work of the performer and the biographer: deciding on a person's main qualities via the textual traces any human being leaves behind. One decides what the person who generated the works "is like." Faculty would not plan and enjoy single-author classes if they didn't have an affinity for an author, and, since our students already leave our classes with vague images in their minds of the authors studied, one is justified in making those images themselves the object of study.

Our Skype Aphra allowed us to ask this particular favorite famous author some juicy questions. But I know what you're still wondering: what exactly did Aphra tell my students about John Hoyle? No spoilers here! If you are as curious as they were, you can either hire Karen, or you can wait until the afterlife, when we're all lifting our pints at the Rose Tavern in the sky.

\section{Works Cited}

Eterovich, Karen. “Love Arm’d, Aphra Behn \& Her Pen.” Love Arm'd Productions. Web. 8 Mar. $2013<$ www.lovearmd.com/aphra.html>.

Woolf, Virginia. A Room of One’s Own. 1929. Adelaide, AU: eBooks@Adelaide, University of Adelaide, 2012. N. pag. Web. 25 March 2013. 


\section{Appendix}

\section{Aphra Behn: Poet, Playwright, Fictionist}

Eng400.06, Spring 2011-Writing Emphasis

Dr. Cheryl Wanko

Main 503, 436-2126

cwanko@wcupa.edu

Office hours: Tuesday \& Thursday 10:30 - 12:30

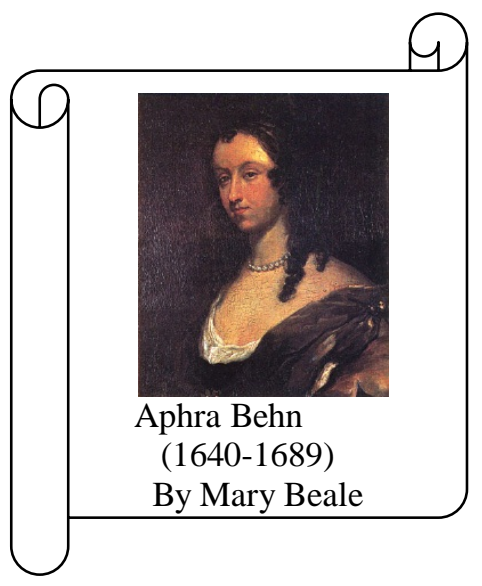

Wednesday $2-3$

And by appointment

Public Safety/Campus emergency number: 610-436-3311

"Intellectually, she was qualified to have led [the playwrights of her day] through pure and bright ways; but she was a mere harlot, who danced through uncleanness, and dared or lured them to follow. Remonstrance was useless with this wanton hussy.”-John Doran, 1888

"Mrs. Behn allow'd herself, of writing loosely, and giving . . . some scandal to the modesty of her sex.”-John Dryden, c. 1690

Traveler, spy, and successful playwright, Aphra Behn wrote verse both formal and bawdy, racy comedies, tales of wayward nuns, and (maybe) the first novel. In this course, we will read her work to understand how Behn negotiated the difficult position of the woman writer at a time when public women were seen as scandalous and to appreciate the breadth and courage of her writing. We will supplement our reading of Behn with selections from the works of some of her contemporaries and revisionists as well, and approach all via historicist and gender-theory perspectives.

\section{Course goals:}

- Build on the general education skills you acquired in WRT, SPK, HIS, \& PHI classes as well as those from your English core courses ENG194, 295, and 296 (or LIT206).

- Read from the wide variety of Behn's works and situate them within her time and culture.

- Learn about the culture of the time and to discuss its impact on and interaction with Behn's works.

- Improve research techniques and information literacy for literary, historical, and cultural work.

- Continue to develop writing strategies, skills, and production.

- Examine how other writers have re-visioned Behn's work for other genres, societies, and times.

- Serve as a capstone pre-professional experience for advanced English majors.

\section{Course requirements:}


- Reading assigned material for each class, demonstrated by active, informed participation, by enthusiastic support of your peers as they give their class presentations, and by participation in workshops (10\% of final grade).

- Short paper on assigned topic (20\%). 3-5 pp.

- Topic proposal for longer paper (15\%). Rationale: to encourage you to begin work on the project early enough in the semester to produce a good one; to inform me of what project option you have chosen; to allow you enough time to secure secondary works through interlibrary loan, through visiting other libraries, or through the net; to demonstrate knowledge of MLA bibliographical style; to allow me to respond to ideas and to provide you with other sources to consult. For secondary sources, you might begin with the class bibliographies on our D2L site or the MLA bibliography online.

- Short quiz on the Oroonoko variations (5\%). Final exam day activity.

- Major research paper or project (25\%). Options: students may propose a traditional essay, an extensive website on a topic relating to Behn (but not a general "Aphra Behn" site, since others already exist), or a thorough, well-developed set of lesson plans. Approximately 12 pages (or equivalent). In class, we will concentrate primarily on the research paper option, since that is usually the most popular. However, if you think you might choose one of the other two, please let me know as soon as you can so that I can modify our class activities.

- Teach 45 minutes of one class: consisting of research report of approximately 10-15 minutes and discussion of the day's text of approximately $\mathbf{3 0}$ minutes (25\%). For one of our class sessions, you will present information and guide class discussion. You will:

1. meet with me at least one week before the date of your presentation to discuss your plans

2. present an oral report on a research topic (10-15 minutes on topics noted below in syllabus)

3. provide at least a five item annotated bibliography for your research topic (at least 2 items must be post-2000; no -pedias)

4. give a short introduction to that day's reading

5. draw connections between your research topic and the day's assigned reading

6. respond to questions others have about your information

7. generate discussion of research topic and reading. You might decide to use discussion questions: What makes a good discussion question?

8. connect your discussion to previous discussions.

This is your show, so use whatever ancillary material you think will help make your day more interesting and informative, such as a list of discussion questions, handouts, PowerPoint or other visual aids, in-class art projects, dramatic readings, costumes, etc.! You may give the class an easy assignment the (class) day before you are scheduled to teach. You will be evaluated on how well you fulfill the expectations listed above, on your preparation, and on the level of interest you generate. Creativity will be rewarded (though not if it doesn't help us better understand your research topic or the day's reading).

Grades: As this is a 400-level class—a class level that assumes you are close to graduation-you will be graded as though you are about to leave the university. You will need to show that you have mastered the type of writing, reading, and production necessary to an emerging professional.

$\mathrm{A}=$ excellent work. Addresses all elements of its rhetorical situation. Has a provocative, original thesis which is well argued over the course of the essay and a well-organized structure that answers readers' questions and concerns as they arise. Thoroughly researched and documented. Incorporates relevant detail and the opinions of other writers without confusing the main point. Professionally presented, with no mechanical errors in grammar, paragraphing, sentences, or citation. 
B = good work. Sensible approach to rhetorical situation. Research goes beyond minimum requirements. Clear thesis and structure, good use of detail, incorporates some original ideas, most mechanical elements are strong.

$\mathrm{C}=$ adequate work. Meets most requirements of rhetorical situation. Thesis indicates a general line of argument, though it may repeat topics we've discussed in class. Covers its points adequately but does not follow up on interesting complexities. Meets minimum research requirements. May have some structural difficulties or may not yet show full command of mechanics.

Other grades $=$ your project will not succeed in persuading its audience. Maybe you have not addressed the rhetorical situation (for example, a proposal that does not try to persuade); maybe your thesis is not clear or is elementary ("Behn's works address many topics relating to women”); maybe you're trying to include too many ideas or maybe you haven't thought about the complexities of those you've included; maybe your structure is arbitrary; maybe the research is incomplete or incorrectly documented; maybe you have made far too many mechanical errors for an advanced English major.

Attendance policy: Because this course's material is complex, you need to be in class to get its full benefit and for others to benefit from your ideas and expertise. Each class missed after three absences will lower your final grade a third of a letter grade (from C to C-, for example). Save your absences for cases of emergency: there are no "excused" absences for illness, car trouble, etc. If class is cancelled, I will email you as soon as possible and post any announcements on our D2L site. You will be responsible for having done the reading for any missed classes on the day we return to class. Entrances/exits disrupt class activity, so two latenesses or early departures will be counted as one full absence; additionally, please visit the restroom either before or after class. Except for medical difficulties, you should have no reason to leave the classroom while class is in session.

Plagiarism \& other academic policies: Someone has worked hard to find information, or think up ideas, or write beautiful or informative sentences, and so you should acknowledge their work and their contributions to our intellectual wealth. Simply put—do not use anyone else's work and call it your own, even inadvertently. If there is a question about “common knowledge” in a particular discourse community, please ask. Otherwise, don’t repeat any information that you didn’t know before, or any sections of writing, or even a sentence of writing from the web, or from another student, or from any other source, without acknowledging its source: if you read or learned it somewhere else, cite it. To use a direct quotation or summary/paraphrase, cite it appropriately using with MLA documentation, which includes both parenthetical reference and Works Cited list. You can find information on MLA style on the web, and at the WCU library's website: http://www.wcupa.edu/library.fhg/help.asp\#cite.

I feel strongly about academic dishonesty, and I will prosecute plagiarists ruthlessly according to WCU's policy, which means the plagiarist can fail the assignment, fail the course, or be removed from the university. For information on all university policies, see the Academic Policies \& Procedures section of your undergrad catalog, the Ram's Eye View, or http://www.wcupa.edu/_INFORMATION/OFFICIAL.DOCUMENTS/Undergrad.Catalog/AcPolPro.htm

Single-tasking: We all practice multi-tasking, and you will need that skill in your later careers and private lives. However, current research indicates that we are not as productive or efficient when we try to multi-task, because of the way our brains process information. Thus, we need to become good singletaskers, and learn how to master the shift of tasking modes when required. You will need to set aside uninterrupted time to read and ponder our class's difficult material. You will also need to put away all electronic devices while class is in session, both for you and for the other students who will be distracted by such activity: no texting, cell phones, or laptops in class (unless special circumstances require them). I consider ringing phones and texting during class as violations of the "disruptive behavior” policy.

Special needs: As a member of the West Chester University community, I wish to make accommodations for persons with disabilities and to comply with the ADA of 1990. To allow me to 
accommodate students with documented disabilities, please inform me of your needs at the beginning of the semester so we can make arrangements. For information and documentation, please contact the Office of Services for Students with Disabilities (610-436-2564) in Lawrence Center 223.

Ally: In completing WCU's Lesbian, Gay, Bisexual, \& Transgender Ally training, I made the commitment to offer a safe space for all of my students, not just those who identify as LGBT. If you or someone you know would like to know more about this program, or needs to speak confidentially about issues of sexual orientation or gender identity, please feel free to see me during my office hours. If you don't want to speak with me, I can also refer you to others with whom you might be more comfortable (see http://www.wcupa.edu/_services/stu.lgb/).

\section{Required texts:}

- Oroonoko and Other Writings, ed. Paul Salzman (Oxford: Oxford UP, 1994)

- $\quad$ The Rover and Other Plays, ed. Jane Spencer (Oxford: Oxford UP, 1995)

- Thomas Southerne, Oroonoko (Lincoln: University of Nebraska, 1976)

- *'Biyi Bandele, Aphra Behn's Oroonoko (London: Amber Lane, 1999)

- The Roundheads (electronic text)

- Poems - electronic texts \& hard copy handouts - sources noted in syllabus below

You must bring a copy of all electronic texts to class. I suggest that you find them and print them out at the beginning of the semester.

\section{Schedule:}

T, 1/18 Intro to course. Historical background. Behn quiz! Choose presentation topics.

R, 1/20 Read introductions to all texts plus short biographies: (1) contemporary biography by Katherine M. Rogers from the Literature Resource Center library database (skim the plot summaries) and (2) "The Life and Memoirs of Mrs Aphra Behn" from The Histories and Novels of the Late Ingenious Mrs Behn (1696), handout. Presentation topics assigned.

T, 1/25 Poetry. "A Ballad on Mr. J.H. to Amoret," "On Mr. J.H. in a Fit of Sickness," "The Willing Mistress" (http://www.cygneis.com/woolf/readings/behn.html), "Song. Love Armed."

R, 1/27 Poetry. "The Disappointment," "On the Death of the Late Earl of Rochester," Earl of Rochester, "The Imperfect Enjoyment" (http://ethnicity.rutgers.edu/ jlynch/Texts/imperfect.html).

T, 2/1 Drama. The Rover. Discuss short paper assignment.

R, 2/3 The Rover, continued. Report 1: Restoration theatre.

T, 2/8 Drama. The Feigned Courtesans. Report 2: profession of the playwright in 17 \& early 18c London.

R, 2/10 The Feigned Courtesans, continued. Report 3: women's lives in the late 17c and early 18c. Short papers due.

T, 2/15 Poetry. Behn, "To the Fair Clarinda, Who Made Love to Me" "To My Lady Morland at 
Tunbridge" (handout), Katherine Philips, "Friendship's Mystery" (http://ethnicity.rutgers.edu/ jlynch/Texts/friendship.html), "Orinda to Lucasia" (http://ethnicity.rutgers.edu/ jlynch/Texts/lucasia.html), Behn's (?) letter to Hoyle from Familiar Letters of Love, Gallantry (1718, get from ECCO, vol. 1, page 38). Report 4: same-sex relationships 17c and 18c England

R, 2/17 Drama. The Roundheads. Available from: hard copy books in library; online (such as http://digital.library.upenn.edu/women/behn/roundheads/roundheads.html); and in 17/18c editions from EEBO and ECCO. You must bring some kind of copy to class. Report 5: 17c politics

T, 2/22 The Roundheads, continued. Report 6: actors and actresses of the late 17c

R, 2/24 Poetry. Joan Philips, “To Madame Behn” (handout); Anne Wharton, "To Mrs. A. Behn" (handout); Behn, "To Mrs. W. on Her Excellent Verses"; Jane Brereton, from "Epistle to Mrs Anne Griffiths" (handout). Behn's dramatic criticism: “To the Reader” from Sir Patient Fancy, The Dutch Lover, and preface to The Luckey Chance. Report 7: women writers of the 17c and early 18c.

T, 3/1 Fiction. The Fair Jilt. Report 8: 17c fictional forms

R, 3/3 Fiction. The Unfortunate Bride. Report 9: Theories \& views of race in the 17c

\section{**SPRING BREAK**}

T, $3 / 15$

Catholics

R, $3 / 17$

T, $3 / 22$

R, $3 / 24$

T, 3/29

$\mathrm{R}, 3 / 31$

$\mathrm{T}, 4 / 5$

$\mathrm{R}, 4 / 7$

$\mathrm{T}, 4 / 12$

$\mathrm{R}, 4 / 14$

$\mathrm{T}, 4 / 19$
Fiction. History of a Nun. Report 10: religion in the 17c, with an emphasis on English \& Anglican attitudes towards Catholics

Fiction. Oroonoko. Report 11: slavery in the 17c

Oroonoko, continued. Report 12: English class system of the 17c and 18c

Oroonoko, continued. Read \& critique sample student research paper.

Prepare for Aphra Behn interview.

Southerne, Oroonoko. Report 13: colonialism in late 17c

Southerne, Oroonoko, continued Topic proposals due

Interview with Aphra Behn!

Southerne, Oroonoko, continued. Report 14: courtship \& marriage in the 17c

Laura J. Rosenthal, "Owning Oroonoko: Behn, Southerne, and the Contingencies of Property,” Renaissance Drama 23 (1992): 25-58.

In-class work on research projects. Bring drafts to class.

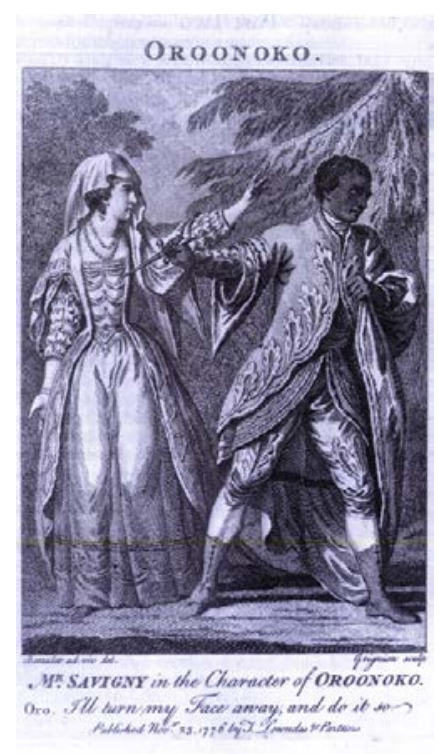


R, 4/21 Bandele, Oroonoko

T, 4/26 Bandele, Oroonoko, continued. Report 15: Behn’s literary/critical history from 17c to present.

R, 4/28 Bandele, Oroonoko, continued. Behn quiz reprised!

Research projects due.

FINAL EXAM DAY:

Tuesday, May 3, 10:30 - 12:30

Quiz on the Oroonokos
All women together ought to let flowers fall upon the tomb of Aphra Behn ... for it was she who earned them the right to speak their minds.
Virginia Woolf, A Room of One's Own

All syllabus images are from Wikimedia Commons. 